\title{
Becoming a part of 'elsewhereness': On the self-perceived integration of Swedish immigrants in Portugal
}

\author{
Daniel Rauhut $^{1}$ (ㅇ | Alina Esteves ${ }^{2}$ (ㅇ
}

${ }^{1}$ Karelian Institute, University of Eastern Finland, Joensuu, Finland

${ }^{2}$ Institute of Geography and Spatial Planning, University of Lisbon, Lisbon, Portugal

\section{Correspondence}

Daniel Rauhut, Karelian Institute, University of Eastern Finland, Yliopistokatu 2, PO Box 111, FI-80101 Joensuu, Finland.

Email: daniel.rauhut@uef.fi

\begin{abstract}
This article discusses the self-perceived integration of Swedes permanently residing in Portugal. The knowledge of how EU citizens, particularly Swedes, live and integrate into Portuguese society is limited. The conceptual framework on self-perceived integration takes its points of departure from the concepts of a sense of belonging to society and place, feelings of discomfort and coping tactics. Using a semi-structured interview guide, 36 in-depth interviews with Swedes permanently residing in Portugal were conducted. Whereas some of the permanently residing Swedes have no ambition of integrating into Portuguese society, others display a strong selfperceived feeling of being integrated within the community where they live. The added value of this paper is that it shows the complexity behind the construction of the feeling of self-perceived integration of Swedes in Portugal. Building a feeling of self-perceived integration depends on many factors and is not a linear process.
\end{abstract}

\section{KEYWORDS}

coping tactics, 'elsewhereness', feelings of discomfort, self-perceived integration, sense of belonging

\section{1 | INTRODUCTION}

The decision of how and where to continue one's working life or enjoy retirement can be taken in different stages of the life course, depending on the perceived possibilities of having a good and fulfilling life somewhere else. This awareness is closely linked to feelings of self-perceived integration, a concept with different interpretations and meanings for different individuals. The factors brought to the fore are diverse and range from a sense of belonging, to feelings of discomfort, fair treatment by other individuals and official agencies, and also the perception of opportunities (Baumeister \& Leary, 1995; Hellgren, 2016; Schellenberg, 2004; Wu, Schimmel, \& Hou, 2012). Space has also been added to the equation, and researchers have highlighted the relevance of integration in place through mobility practices, where knowing the place-based structures allows a person to navigate his/her surroundings and leads to feelings of attachment to the place (Åkerlund \& Sandberg, 2015; Haldrup, 2004). Other authors stressed belonging to a place being linked with identification with the place, feelings of being at home in a location, familiarity with a place being achieved with prolonged stays, and engagement with activities made possible in the location helping to build connections with it (Antonsich, 2010; Juang et al., 2018).

However, bonds to people and places are rebuilt and redesigned, and individual decision-making is adapted to the constantly changing surroundings (Benson \& Osbaldiston, 2016; Palese, 2013). In a time of fluidity and happenstance, the need to readapt and rethink one's life plans according to changing economic and social frameworks requires flexibility of the mind and adaptability (Palese, 2013). The search for a more fulfilling life in another country is certainly moulded not only by an individual's ability to mobilise their capital (human, financial and social) but also by structural frameworks that constrain the outcomes (O'Reilly, 2012). Choosing a destination is based on weighing a set of variables and assessing the perceived gains and losses of a decision, either in the short and/or in the long run. When migrants settle down in a new environment, there is a need for embedding with the people and the place, hence fostering a sense of belonging (Åkerlund \& Sandberg, 2015; Ryan \& Mulholland, 2015). Different tactics can be mobilised by migrants in order to nurture feelings of being part of the 
hosting society, depending on their expectations and perspectives for the future. Their self-perceived integration can have different meanings and amplitudes, involving life projects of diverse duration and commitment. Acquiring resident status in a new location can lead to long stays and deep social and local intertwining but does not necessarily involve a definite move, even if to a foreign country (Montezuma \& McGarrigle, 2018). Economic and class restructuring, as well as changing migration policies, may create new constraints, and other moves and living rearrangements need to be considered in order to live comfortably or fulfil aspirations of well-being (Åkerlund, 2015; Hayes, 2015; Korpela, 2009). For migrants aged 60+, the practice of privilege when moving to a new country may be part of their sense of belonging (Scuzzarello, 2020).

With this framework in mind and drawing on the literature pertaining to lifestyle migration and sense of belonging, this paper aims at discussing the self-perceived integration of Swedish citizens, holding permanent residence entitlement in Portugal. Through their narratives, distinct ways of designing and building integration are explored, showing diverse kinds and levels of involvement with the host society in the location they have chosen to live. Their subjective assessment of their own integration in Portugal is analysed through the concepts of a sense of belonging and feelings of discomfort, two of the most frequent variables used in this kind of study. In order to perform this analysis, four questions from an extensive interview were chosen: (1) How do the Swedes see their place of residence? (2) How do the Swedes interact with the Portuguese? (3) How do the Swedes in Portugal live? (4) What importance does proficiency in the Portuguese language have for becoming part of the local community?

\section{2 | LIFESTYLE MOBILITY TO PORTUGAL AND INTEGRATION: DO THE SWEDES FIT IN?}

Portugal, together with Spain, Italy and Greece, has been hosting foreign citizens from more affluent societies for quite a long time. British, Germans and Dutch compose the older communities of sunseekers (King, Warnes, \& Williams, 2000), whereas Scandinavians (Rauhut \& Laine, 2020) and French have settled more recently (Lestegás, LoisGonzáles, \& Seixas, 2018). The growing presence of EU nationals in the country is partly the result of the active policy implemented by the Portuguese authorities to attract retirees, highly skilled migrants and investors by way of tax exemptions, Golden Visas and other permits that give permanent residence entitlement (Ampudia de Haro \& Gaspar, 2019). With this policy, the Portuguese authorities presume that foreigners will find permanent living in the country to be attractive and advantageous. However, previous research shows that the idea of permanence can be understood in different ways by individuals. Accommodating change in one's life requires celerity, and residing permanently in a place can be re-evaluated according to structural or conjunctural changes and also to happenstance (Machado, McGarrigle, Fonseca, \& Esteves, 2019). Moreover, recipients of permanent residence permits can make a more 'rational' choice and equalise the duration of their residence to the length of the privileges attached to the entitlement. Thus, when the legal document expires, they look for other destinations with more advantages (Montezuma \& McGarrigle, 2018).

Knowledge regarding how EU citizens live and integrate into Portuguese society is limited, especially in respect of systematic and encompassing qualitative studies (Oliveira \& Gomes, 2019). Current research findings suggest that several groups of EU nationals opt for conviviality with co-nationals and other expats, placing themselves apart in a kind of bubble of privileged citizens (Croucher, 2012; Fechter, 2007). Many British migrants in Spain and France have faced challenges integrating into their local communities (Benson, 2009, 2013; O'Reilly, 2000, 2017), whereas Swedes (Olsson, 2017) and Finns (Könnilä, 2014) in southern Spain prefer socialising with each other, rather than participating and integrating into Spanish society. Similar findings are also seen for retired British, German and Nordic citizens in Spain (Casado-Díaz, 2006). With a limited proficiency in the Portuguese language, or even adopting the practice of not speaking Portuguese, British migrants in densely populated coastal areas easily place themselves into a self-marginalised existence (Torkington, 2015). However, this does not prevent them of feeling that they belong to the place where they have chosen to live, depending on the time that is spent living in the region (Torkington \& Perdigão Ribeiro, 2019), and German migrants in Western Algarve have also been shown to have similar feelings (Herbers, 2017).

Lifestyle migrants to the inland areas of central and southern Portugal appear to mingle with the Portuguese local society and show a willingness to embrace the Portuguese culture and lifestyle (Sardinha, 2015). One reason for this may be that there are few foreigners in these areas to begin with, so it is necessary to learn the language and customs. Sampaio's (2011) study in low-density areas in the hilly region of the Algarve remarks on the efforts that German retirees make compared with English native speakers to learn Portuguese, showing a stronger commitment to engage with the local daily life. A need to be part of the local community has also been felt among a group of Dutch and Germans in a small rural community in the Alentejo region, and by taking care of the farming land, they have symbolically filled the place left by earlier Portuguese rural wage earners in the local social structure (Raminhos, 2004).

Being a small, discrete group of 4,912 persons (Instituto Nacional de Estatística [INE], 2020) from a highly developed country, the Swedes living in Portugal have never caught the attention of Portuguese researchers. Thus, there is no research on how Swedes in Portugal integrate, or on how they perceive their own integration. They are neither listed separately in, for example, the statistics on foreigners' labour market performance in Portugal (Gabinete de Estratégia e Planeamento, 2018), nor is their situation in the Portuguese housing market (INE, 2019) remarked. In Sweden, the Swedish citizens permanently residing in Portugal are imagined as being wealthy and as those who try to avoid Swedish taxes and enjoy free access to Portuguese health care. Being expats, they are supposed to live in ethnic enclaves with little interest in Portugal or the Portuguese people, and this description has been actively communicated in 
media by the Swedish government (Aftonbladet, 2019; Dagens Arena, 2017).

However, the reality of the situation is far more complex than this. Not all of the Swedes are well-off, nor do they live apart from the native population (Rauhut \& Laine, 2020). Thus, their diversity of situations makes this research quite pertinent, especially when the Portuguese government is actively seeking to attract foreigners seen as bringing talent, human capital and investment through tax exemptions and facilitated residential permissions (Montezuma \& McGarrigle, 2018).

\section{3 | THE SWEDES IN PORTUGAL}

Although migration flows between Portugal and Sweden have been marginal, noteworthy changes have occurred in the number of Swedish citizens permanently residing in Portugal. From approximately 1,520 people in 2006 , the number halved in 1 year when the financial crisis hit Portugal in 2008 (INE, 2019). However, the increase in stock of Swedish citizens permanently residing in Portugal is marked after 2014 by a steady growth rate, reaching slightly more than 4,900 people in 2019 (Figure 1). Swedes accounted for $0.4 \%$ of the total number of documented foreigners in Portugal in 2006, and by 2019 , this had risen to $0.83 \%$ (INE, 2020).

The age structure of Swedish citizens permanently residing in Portugal has changed over time, and the decade between 2008 and 2018 saw a remarkable increase in the relative weight of the 50-64 (23.0\% to $34.6 \%)$ and $65+$ year $(21.7 \%$ to $30.8 \%)$ age groups (INE, 2020). This means that whereas a considerable group of citizens is still of working age, retirees are also numerically relevant.

However, although 1,318 Swedes permanently residing in Portugal were aged 65 or older (INE, 2020), only less than 800 Swedes entitled to a Swedish pension were registered by the Swedish Pensions Agency (2019) as permanently residing in Portugal in October 2019 (Figure 2). Hence, about two out of five Swedish citizens aged 65+ years permanently residing in Portugal did not receive a Swedish pension, which leads us to wonder about their livelihoods.
Swedes follow the settlement pattern common to most foreign citizens in Portugal, by clustering in the Lisbon Metropolitan Area (45\%) and in the Algarve ( 45\%), a trend reinforced since 2008. Less than $10 \%$ reside in the rest of Portugal (Rauhut \& Laine, 2020). In the latter area, the municipalities of Loulé, Albufeira and Portimão appear to be hotspots for Swedes (Swiss Economic Forum, 2020).

An analysis of Swedish immigrants' areas of origin in Sweden in 2008 displays a dominance for the three metropolitan areas around Stockholm (Stockholm region), Gothenburg (Västra Götaland region) and Malmo (Skåne region), and Halland in southern Sweden. In 2018, two major trends are visible: (1) Swedes migrating to Portugal come from all parts of Sweden and (2) the dominance of the three metropolitan areas and Halland prevails. Moreover, regions with bigger cities (>100,000 inhabitants) also stand out as sending areas to Portugal (Rauhut \& Laine, 2020).

\section{4 | METHODS AND MATERIAL}

In order to understand how Swedes in Portugal self-perceive their integration into their new society, 36 in-depth interviews were conducted with Swedes permanently residing there. The selection of the respondents was non-randomised, and a notice was placed on Facebook in the closed groups 'Svenska Portugalvänner' ('Swedish Portugal Friends') and 'Svenskar i Portugal' ('Swedes in Portugal') to recruit interviewees for the study. Technically, the convenience sample used is a non-probability sampling method, and there are no inclusion criteria except that people are available and willing to participate. This kind of sampling is recognised as being good for pilot studies and when the researcher wants to get in touch with groups who may be difficult to reach (Rubin \& Babbie, 2010). However, samples collected in this way may not represent the population of interest and can therefore be biased. Thus, in line with the standards of qualitative methodology, generalisations to the whole population cannot be made (Robson, 2002). Rather than generalising the results from sample to population, this study has the ambition to explicate relevant

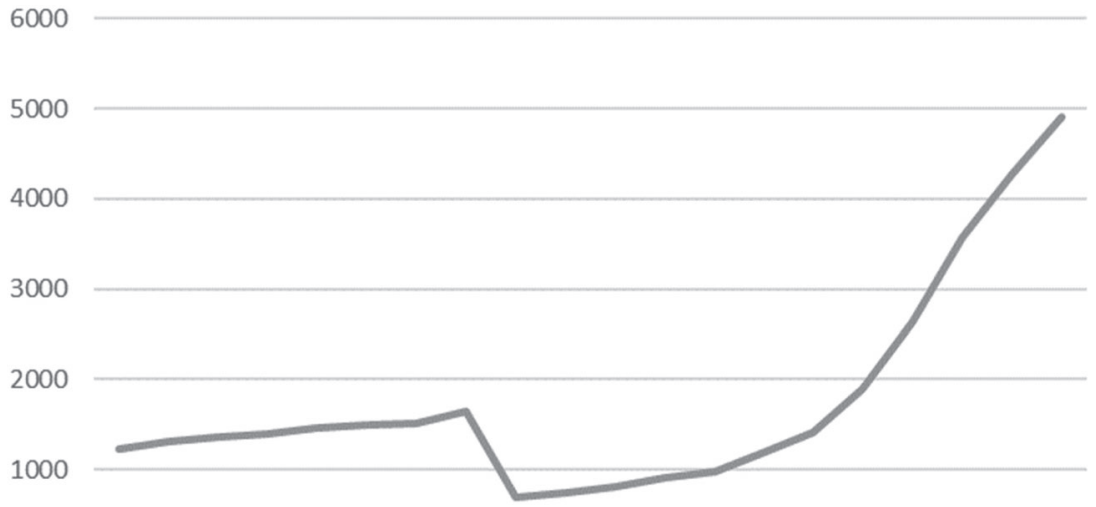

FIGURE 1 The number of Swedish citizens permanently residing in Portugal 2000-2019. Source: Instituto Nacional de Estatística, 2020

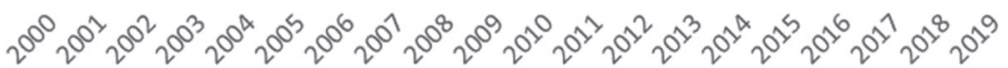




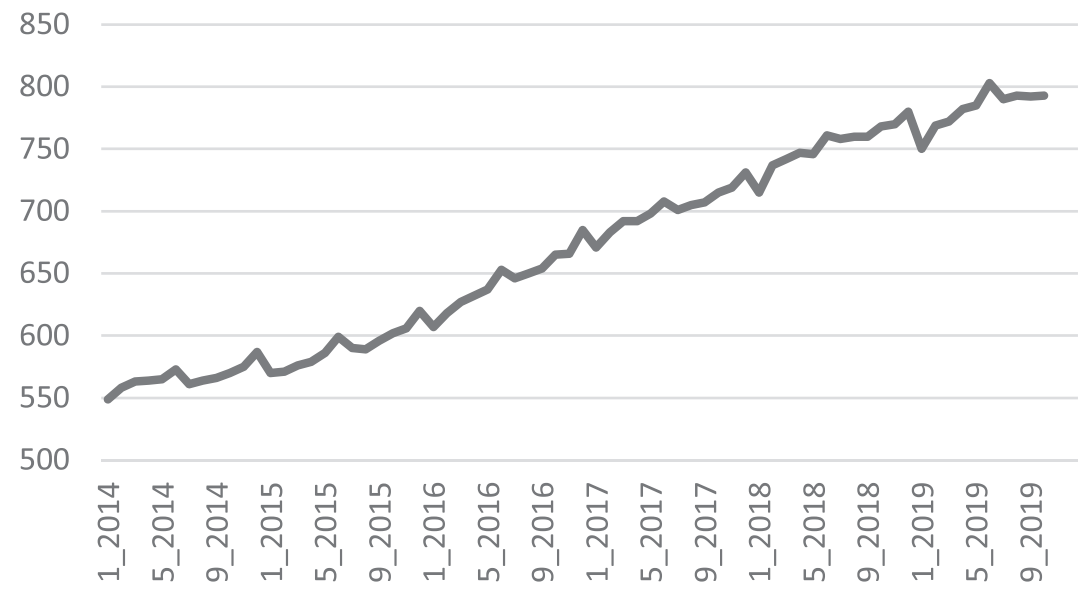

FIGURE 2 Swedish pension beneficiaries permanently residing in Portugal 2014-2019. Source: Swedish Pensions Agency (2019) analytical themes and stereotypes on the self-perceived integration of Swedes permanently residing in Portugal.

In total, 75 people responded and 38 were selected for interview. The main selection criterion was that the respondent was a registered permanent resident in Portugal and not a second homeowner. Two of the planned interviews never took place. For the 36 in-depth interviews conducted, most took place in the home of the interviewee and some in cafés or restaurants chosen by the interviewee. As some of the respondents lived in remote areas and in the Azores/Madeira archipelagos, five interviews were conducted remotely via Skype. A profile of the respondents is presented in Table 1.

The interviews followed a semi-structured format, which was designed according to a life course approach. Such an approach was used to identify complex motivations in the interviewees' life-work interface and outline pre-migration and post-migration trajectories as they unfold in the immigrants (and their significant others') life course, thus helping to understand the migration processes from the migrants' perspective (McAuliffe, Kitimbo, Goossens, \& Ahsan Ullah, 2018). This research design enables a deeper understanding of the dynamic factors influencing the migration process and their embedded interrelationships. The questions asked covered contextual factors (e.g., employment situation, education, income, family background and other cultural frameworks), why the respondents had decided to leave Sweden for Portugal and how they interact with Portugal and the Portuguese in their daily life.

\section{5 | A CONCEPTUAL FRAMEWORK}

Despite being a contested concept, integration is still a remarkably relevant issue in migration policy debates and a target often expected to be reached by migrants. Instead of narrowly favouring a specific integration model and seeing how Swedes fit in, we prefer to bring up several definitions of integration highlighting the diversity of focus given to its central points. For Heckmann (2006, p. 18), integration is 'a generations lasting process of inclusion and acceptance of migrants in the core institutions, relations and statuses of the receiving society', meaning that distinct processes occur in different domains. Esser (2001) points out four dimensions for gauging migrants' integration: culturation (similar to socialisation), placement (position in society), interaction (social relations and networks) and identification (belonging).

Integration can also be seen as a non-normative concept, and more recent approaches focus on the relationship between migrants and the hosting society rather than on the individuals alone. GarcésMascareñas and Penninx (2016, p. 14) define integration as 'the process of becoming an accepted part of society'. This is quite an open definition as it does not specify how and to what extent the migrant is accepted by the hosting members, nor does it say how much change has to take place on both sides to accommodate difference. GarcésMascareñas and Penninx (2016) propose three analytical dimensions to assess migrants' acceptance (or not) by the hosting society: (i) the legal-political, (ii) the socio-economic and (iii) the cultural-religious. The first dimension pertains to residence, political rights and statuses. The point here is whether foreigners have full status as members of the political community, and their situation can range from being an undocumented migrant to being a national citizen. The second dimension refers to access and participation in sectors like the labour market, housing, health care, education and welfare, comparative to national citizens holding similar skills and qualifications. The interesting point is seeing how migrants perform compared with nationals. The third dimension addresses perceptions and practices of both migrants and the hosting society and their mutual reactions to diversity. The degrees of acceptance of difference (either in public or private spheres) can be very distinct, as well as the expectations of conformity with, for example, culture, traditions and religious manifestations.

To large extent, integration is a subjectively perceived condition. When constructing a conceptual framework, the link between the aforementioned dimensions and the interviewees' statements has to be through their perceptions/opinions. How the immigrants 


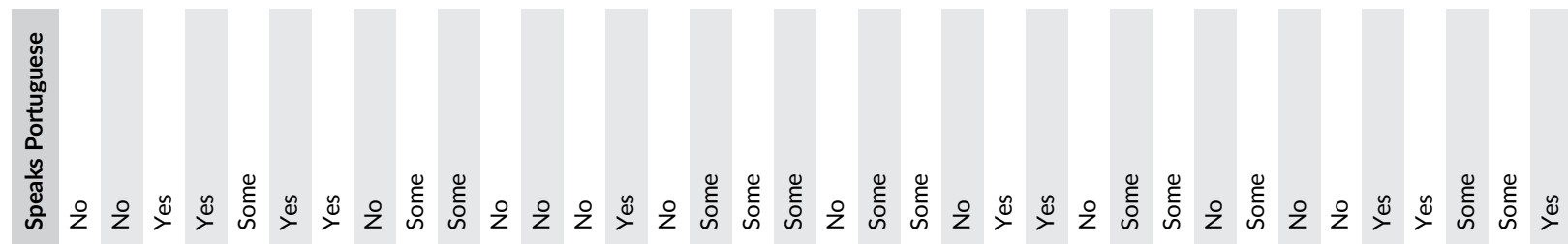

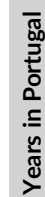

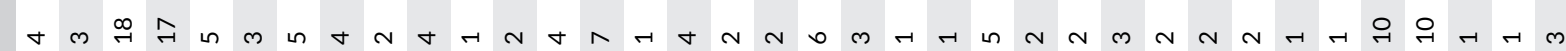

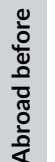

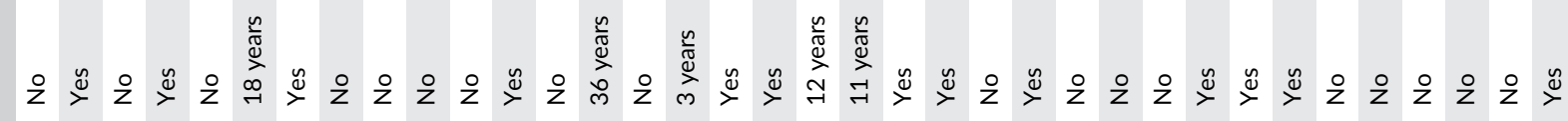

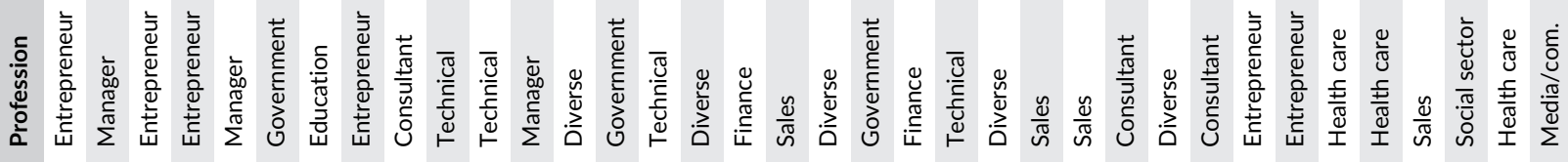




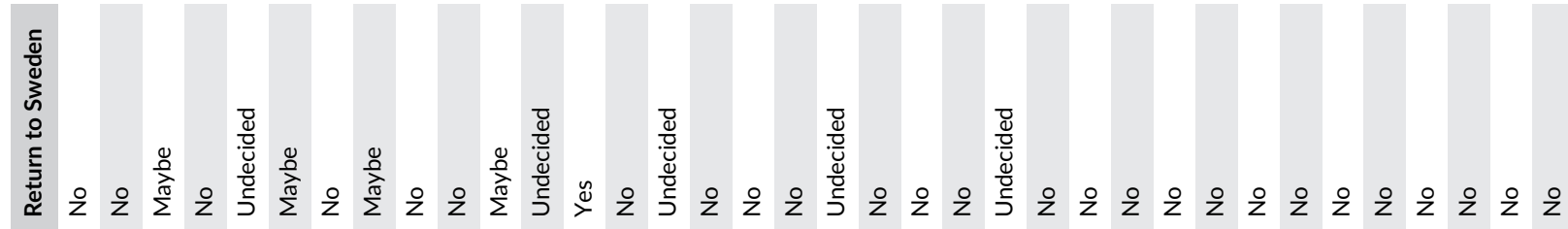

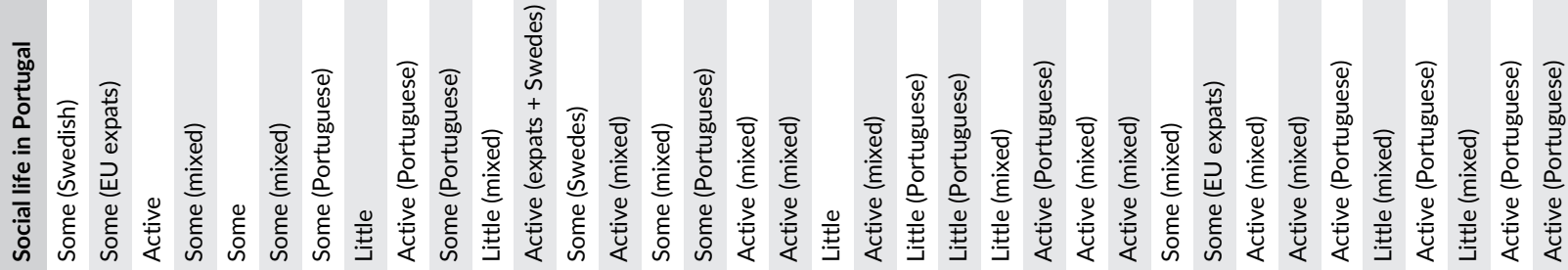

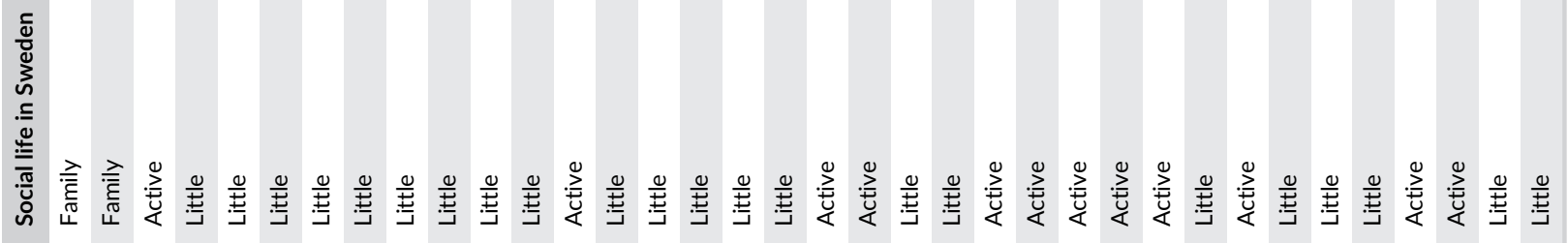

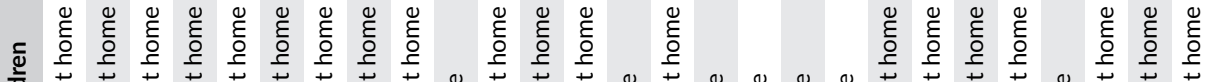

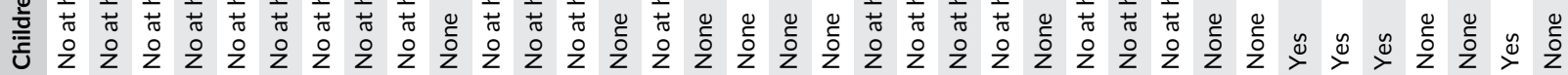

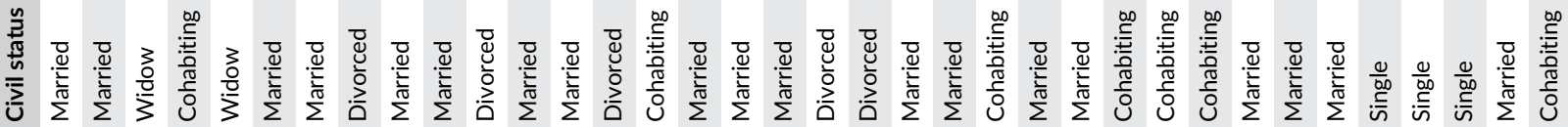

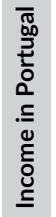

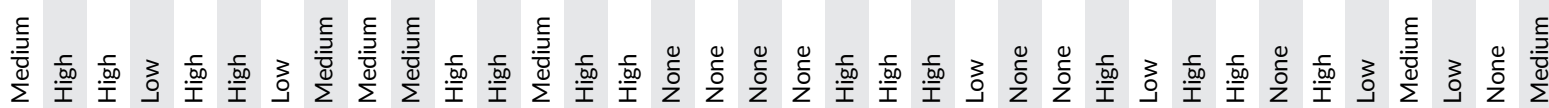

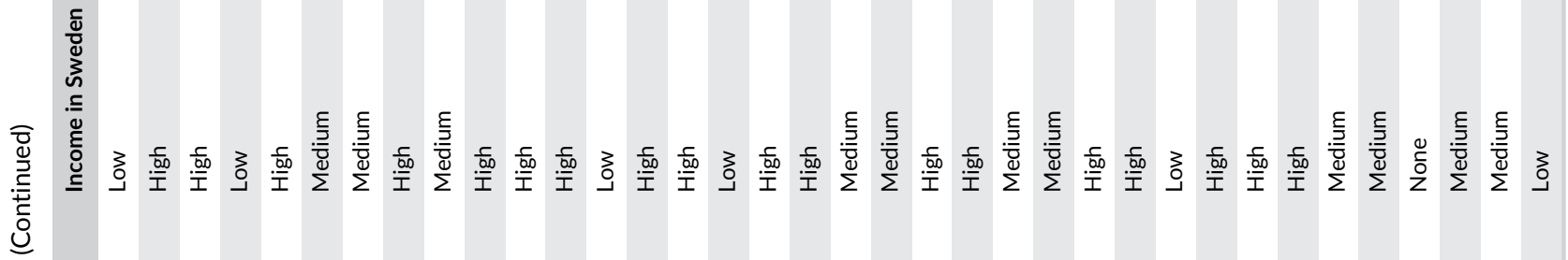

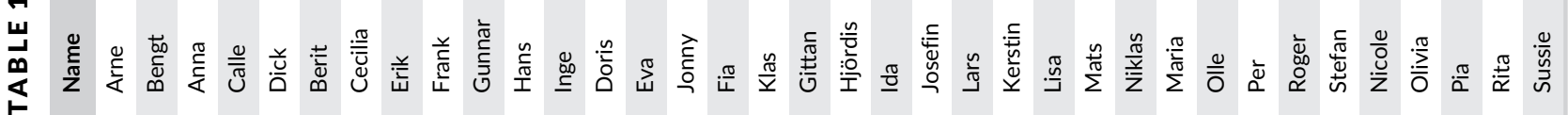


perceive, see and feel their degree of integration in the new country must be in focus, just as how the natives perceive, see and feel the degree of integration of the newcomers. However, this study only focuses on the self-perceived integration of the Swedish immigrants to Portugal.

Previous studies on migrant's perceptions of integration suggest that perceiving to be part of a more complex social whole (to belong) and feelings of discomfort when living in the hosting society are two variables often used to evaluate migrants' subjective well-being (Wu et al., 2012). Recent research also suggests that sensing that one is not part of or does not belong to a group and feeling uncomfortable in daily situations leads individuals to find ways of dealing with the constraints caused by these perceptions, and they may adopt coping strategies or opt for tactics to deal with their situation (Machado et al., 2019). The migrant must be willing to become a part of the new community in which s/he lives to become integrated (Rauhut, 2020a). These three aspects-a sense of belonging, feelings of discomfort and coping strategiesare considered key elements to achieve a subjectively perceived feeling of integration.

\subsection{Sense of belonging}

Psychologically, the need to belong is a fundamental human motivation (Baumeister \& Leary, 1995). Being intimately involved with the surrounding society through social networks can give us a sense of satisfaction and inclusion, as interaction between people builds community and offers a sense of connectedness (Schellenberg, 2004). A sense of belonging is closely related to the feeling of being a member of the society, that is, to have a positive regard from and for others. Belonging is also associated with a commitment to stay in the destination country (Chow, 2007) and to build primary relations in the host society (Wu et al., 2012). Here, primary relations are understood as forming a very personal, spontaneous and inclusive relationship that involves complete personalities like the relationship between close friends or between spouses (Davis, 1949). Interactions with neighbours and a familiarity with the local environment play a significant role in making people feel at home, and Liu et al. (2020, p. 3) view that 'This feeling of being at home cultivates a sense of belonging to the place where one resides'

The attachment to a location is constructed by living there, mingling with the locals and cruising it (Haldrup, 2004). According to Åkerlund and Sandberg (2015), holding a dwelling, and through mobility practices like knowing one's whereabouts, being able to move around, and finding the basics needed for daily life will increase the feeling of familiarity. In turn, this changes space into place, by giving it meaning and significance.

There is also a temporal aspect of staying in a certain place. The longer one stays, the more familiar it becomes. Cuba and Hummon (1993, p. 550) conclude that 'research on people's attachments to particular neighborhoods or communities also documents that emotional ties to these locales grow in strength over time, in part because long-term residence imbues the landscape with the meanings of life experiences, and in part because such residence nourishes local ties to friends, kin, and community organizations'.

\section{2 | Feelings of discomfort}

Feelings of discomfort in a society are incompatible with a sense of belonging to that society. In a Canadian study, perceptions of exclusion and marginalisation are found to go hand in hand with the feeling of discomfort, and social and civil participation are needed for social inclusion (Reitz \& Banerjee, 2009). Wu et al. (2012, p. 384) conclude that '[i]n this respect, feelings of discomfort are a proxy for the perceived social distance between immigrants and the Canadian-born'.

Feeling uncomfortable or out of place in a hosting society is often reported as an initial perception associated with newcomer status and socialisation in a foreign cultural environment. The notion of cultural distance (Kaasa, Vadi, \& Varblane, 2016) must be brought into the debate. Migrants may feel uneasy when confronting cultural disparities between their origin and the destination society (KhovanovaRubicondo \& Pinelli, 2012). The absence of certain shared values may be more often felt when migration occurs between countries with a very large cultural distance. Sometimes, practical aspects of daily life such as dealing with bureaucracy (Belabas \& Gerrits, 2017) or different social conceptions of punctuality (Birth, 2004) or professional honesty can become huge challenges for newcomers who bring other references from home. Thus, the more unfamiliar a new country, its people and its culture are, the more feelings of discomfort and vice versa.

Language is a key for integration. A low proficiency in the native language is an additional challenge to understanding the "nuts and bolts' of complex issues like regulations and laws and poses a barrier to socialising on a daily basis and understanding socio-cultural codes (Esteves \& Sampaio, 2013). By not speaking the language, parts of the new country, its culture and people will remain unfamiliar.

\section{3 | Coping tactics}

Designing strategies to overcome daily challenges in a new country of residence is essential to building a bearable life. However, this assumes that the migrant asserts agency and capability to adaptation (De Certeau, 1984). Machado et al. (2019, p. 30) resort to this concept when exploring Brazilian and British migrants' '... routines of everyday practice acting within the more powerful strategies defined by institutions or organized bodies' in Portugal. This approach highlights their capacity to navigate the system by learning with locals how to mobilise various types of capital assets (Datta et al., 2007). To learn from the locals means that the migrant becomes familiar with what is needed for living their everyday life, which in turn helps to turn space into place. A proficiency in the local language will facilitate this process. 


\section{6 | THREE TALES OF SELF-PERCEIVED INTEGRATION}

The 36 respondents of this study can be arranged into three different groups in terms of their self-perceived integration into Portuguese society. The grouping of the respondents is based on a cluster analysis made by Rauhut (2020b), based on the same empirical material. Three main clusters are identified (Table 2). The first cluster contains respondents with different forms of personal problems. The respondents in the second cluster have come to Portugal to enjoy privileges, 'the good life' and the sun. Lastly, the respondents in the third cluster have ended up in Portugal for various reasons, including work, family ties or a 'familiarity' with the country.

An interesting result highlighted by Rauhut (2020b) is that the settlement patterns in Portugal differ significantly between the three main clusters. As discussed in the conceptual framework, where you live and settle down will have an impact on the sense of belonging and consequently on the self-perceived feeling of being integrated into Portuguese society. Hence, the self-perceived integration of the Swedes permanently residing in Portugal will build on this typology.

\section{1 | Escapers}

The first cluster contains people with various forms of personal problems that 'push' them away from Sweden. Leaving Sweden was seen as an attempt to change their course of life in a more favourable direction. The members of this cluster can be described as having the following characteristics: on average, they have stayed about 4 years in Portugal, and they do not speak Portuguese. They rent their housing, but they live amidst the Portuguese. Few have any contact with other Swedes; the social life they have is based on English-speaking Portuguese or EU expats. They have nothing to return to in Sweden.

With the exception of one respondent who has lived in Portugal for almost 20 years, the persons in this cluster have not yet developed any sense of belonging. Erik (male, 66) notes that he has 'a lacking social attachment. This is the worst'. Several of the respondents in this group have already moved between different locations in Portugal in search of somewhere to settle down. During the time they have stayed in Portugal, some feelings of discomfort can be identified. 'We've noted that there's a bureaucracy and there're lots of papers to be signed ... and stamped', says Stefan (male, 40). So far, they have not developed any coping tactics.

\section{2 | Practicing privilege}

The persons in the second cluster have moved to Portugal to enjoy the climate and 'the good life'. However, some have health problems that have been mitigated by moving to a warmer climate. Returning to Sweden is not an option for these people. The persons with health problems live amidst the Portuguese in housing they own, and they have a social life containing Portuguese, EU expats and Swedes. They have a good proficiency in Portuguese, and they perceive themselves as being integrated into the Portuguese society. However, this is the contrary to the other members in this cluster, and generally, the members in this cluster display a low proficiency in Portuguese, live predominantly in gated communities with other expats and do not generally perceive themselves as integrated. Indeed, some of them have no ambition of being integrated. There is also an ideological motive for emigrating: they vote conservative and dislike the redgreen government in Sweden. Six of the seven persons who enjoy Non-Habitual Resident (NHR) status are to be found in this cluster.

Among the respondents in the second cluster, only a few display a high proficiency in Portuguese, and four have no intention to learn the language. Their social life in Portugal is dominated by fellow compatriots and EU expats, mostly English and Dutch because they speak good English. Moreover, they have no interest in socialising with the native population. As Inge (male, 65) explains, 'Portuguese is a very difficult language to learn/ ... /we don't socialize much with the Portuguese/ ... /There are many English, Dutch, French and Swiss we socialize with through the golf club. There are also many Irish'.

For most persons in the second cluster, it is important to socialise with the 'right' (Swedish) people in Portugal, be active in the 'right' clubs for Swedes in Portugal, to eat at the 'right' restaurants and so forth. Their place in the social hierarchy among other Swedish expats is a social construction based upon the exclusivity of being a member of the 'Swedish community' in Portugal. Living in this kind of social bubble, Croucher $(2012$, p. 3) has viewed that '... these migrants of privilege are not assimilating ...'. Several show no wish to be part of the larger society or to establish primary relations with the Portuguese, and that is fine for them.

Many people from this particular group demand supermarkets with Swedish products, Swedish artisans, Swedish restaurants and so forth. Regardless of how long they have lived in Portugal, they say home when they speak of Sweden. Portugal is seen as a foreign country and they usually label it as here. Anna (female, 72) is very clear when talking about where home is: 'I spend four and a half months at home every year'. The rest of the year is spent in Portugal. 'I also do my shopping in a shop with Kalles kaviar [a Swedish caviar] and Annas pepparkakor [ginger breads]. They also have Wasa knäckebröd [a Swedish crisp bread]'. This group also talks about the 'local population' when they refer to the native Portuguese. Despite not wanting to build deeper relations with the natives and socialising in exclusive groups of expats, none of this group expressed any plans for longterm stay. Benefitting from NHR status, many will make a decision of where to live when the 10-year fiscal status expires.

The members with health problems in this cluster intend on staying, and they have a good proficiency in Portuguese. They also have a different attitude towards the Portuguese society. "Many complain it's difficult. Yes, it is, but we've chosen to move here. So, we have to adjust to life here. I've chosen this myself, so now I have to adjust', says Maria (female, 49).

There are situations that make the respondents in this cluster feel discomfort, and they complain about many things. Anna (female, 72) is disappointed that the Portuguese 'are not good at bringing bad news. 

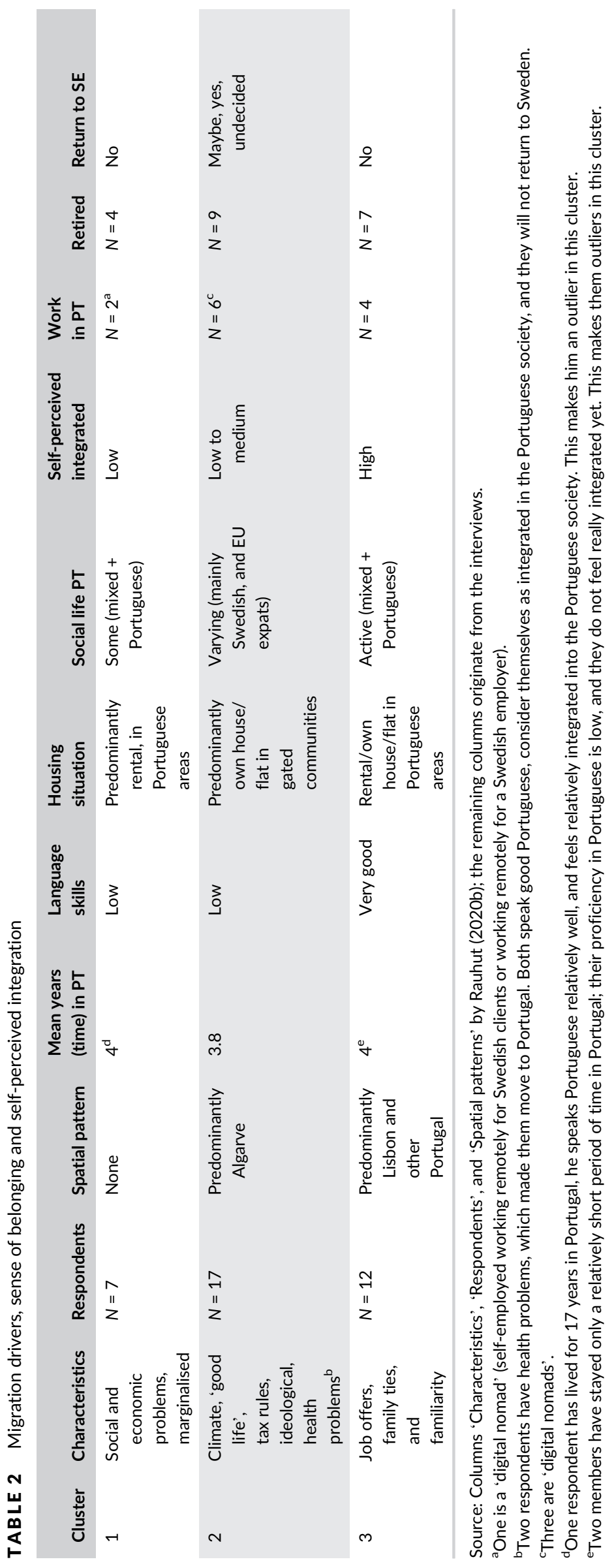
They don't like it and therefor they don't say anything. This make the information they give unreliable. They can't keep any timetable and they're lousy at planning things/ ... /It's difficult to get used to'. Other areas of discomfort were also mentioned. Bengt (male, 77) complains that 'They are so dodgy here. There are so many old-fashioned rules here/ ... /the bureaucracy and the contact with authorities are horrible/ ... /Sometimes they can't speak English, they just say "português, português" '. Few of the members in the second cluster have any coping tactics, partly because they have no interest in becoming a part of the Portuguese society.

\section{3 | Jobs, love and familiarity}

The last cluster contains three groups displaying different characteristics. The first group contains people who came to Portugal due to job offers. They have a very good proficiency in Portuguese, have work in Portugal, live amidst the Portuguese and perceive themselves as integrated. They are happy with their lives and have no intentions to return to Sweden. Moreover, if they ever have to leave Portugal for some unforeseeable reason, it is more likely that they will move to another country rather than return to Sweden.

The characteristics of the second group are very similar to the first, with the exception that these people have come to Portugal due to family ties. The third group consists of persons who have, for example, worked for many years in Portuguese-speaking countries in Africa or have worked in the EU. Instead of returning to Sweden, these persons moved to Portugal. This group also contains persons who have worked in many countries and decided to move to Portugal because they felt familiar with the country.

Many respondents in this cluster are of working age and work in Portugal. When they speak of the place where they now live, they refer to it as home. Sweden is not home, but the country in which they lived before. Moreover, when describing the friends and family they left behind, these persons live in Sweden and not 'back home'. Lisa (female, 55) says that "we've stopped saying "home" when we talk about Sweden', and this indicates a sense of belonging and attachment to the place they live in.

Most of the people in this group are active in different social settings, such as clubs, associations or charity work. One person is active in Centro de Dia (Day Centre), a charity and/or state-run organisation helping elderly people. Another person is an active member of the village board in the village she lives in. Several respondents are active in different sports clubs. Often, the interviewed Swedes are the only non-Portuguese members in these clubs, and the language spoken in these clubs and associations is Portuguese. Olivia (female, 31) explains, 'I'm very active in a cross-country running club here. Basically, all of those I run with every weekend are Portuguese'. Niklas (male, 55) has similar experiences: 'I compete in orienteering and when I practice on Wednesdays in the club it's just Portuguese athletes'. By investing time and energy in these Portuguese-based organisations where they are a small minority, Swedes nurture a sense of belonging to the local society and they build primary relations. The ties they build with other members, mostly Portuguese, make them feel on an equal footing because they can mobilise different capital assets (expertise, contacts, knowledge, time, etc.) and actively contribute to the activities.

Many of the respondents in this group rent their house or flat, and some have bought a house or flat that needed repairing. Buying such a house or renting is seen as an alternative when available financial resources are relatively limited. These houses or flats are seldom found in the touristic hotspot areas but generally in places with native Portuguese or in the countryside far away from the beaches and tourists. Mats (male, 55) explains, 'There's no need to buy something flashy and expensive, but something cheap/ ... /we bought a house out in the bush ... The house has all we want, but it needs some love and care ... our housing costs are very low'. Contrary to those practicing privilege, the members of this group have no need for flashy bungalows or flats in gated communities.

'If you move to another country, you have to give $110 \%$-you have to become Portuguese. / ... / We want to become part of the community here', says Lisa (female, 55). By observing how the Portuguese society functions and how natives sort out daily challenges like bureaucratic procedures, those Swedes with an interest in integrating into Portuguese society were able to develop tactics that allow them to make life in the country possible and even pleasant. Nicole (female, 39) recalls that 'In the beginning it was very confusing and frustrating/... /When you've lived here for a while, you take it easier. You don't get stressed out. If something is wrong, you have to return back to the tax office or whatever office with the correct papers ... you're mentally prepared for it'. Olivia (female, 31 ) expresses a similar experience: 'It's a very bureaucratic system, but what I really appreciate here is that everybody is so friendly. It makes me overlook the fact that it sometimes takes quite a bit of time to solve something simple/ ... /When I had just moved here I found this very stressful, but after a while you learn that this is nothing to get excited over'. Lisa (female, 55) uses a different tactic when dealing with the Portuguese bureaucracy, by showing informational capital strategically mobilised for the challenge: 'I go to the EU's information page. Every time I have to deal with the administration here, I visit that web portal to see what the rules are here in Portugal and how to deal with it in Swedish. Then I print the page in Portuguese and bring it with me. So far, I have never had any problems'. These narratives illustrate the attitudes that Swedes permanently residing in Portugal have concerning integration and the tactics they deploy to overcome daily challenges.

\section{DISCUSSION}

A sense of belonging and feelings of discomfort are two of the most frequently used variables to assess the self-perceived integration of migrants (Wu et al., 2012). The willingness to be part of a social whole can take different forms. From learning the host country's language, to living among natives or being affiliated to clubs and organisations where national citizens are the majority, foreigners nurture the feeling of being part of their hosting society. In the case of north European 
citizens in Southern Europe, previous research often points to an 'expat way of living', in which social relations are mainly built among fellow countrymen or other foreigner citizens of similar social status, with little exchange with natives (Benson, 2009). There are, however, studies highlighting the efforts and commitments made by Germans and Dutch in small rural villages, in order to feel part of the local community (Morén-Alegret \& Wladyka, 2019; Sardinha, 2015). The adoption of tactics (Machado et al., 2019) (some of which are learned with natives) is a way of coping with life's daily challenges such as navigating bureaucracy, dealing with different conceptions of time or managing perceived 'dodginess'.

Many of the interviewees of the group exercising privilege expressed little desire to be a part of the Portuguese society and are fine with this position. Therefore, one may question if it makes sense to talk about integration at all. This is a small group of extremely welloff people, and this group does not socialise with ordinary commonsonly with people at their own level. This kind of economic upper class live in their own bubble and do so independent from whatever country they originate from. Their lives are sealed off from ordinary people, and this has also been the case in their native countries. When members of this group speak of 'home', it refers to Sweden and not to where they live. This indicates a lack of commitment to the place they stay in (Chow, 2007) and absents any intentions of building primary relationships in the host community (Wu et al., 2012). Aspects such as a sense of belonging and coping tactics become irrelevant. To some extent, this group consists of privileged persons who move around in search of the best conditions each country can offer, for example, in the form of tax exemptions. When they find something better, they simply move to another country, thus giving some food for thought about the pertinence of granting permanent residence permits to NHR holders. However, most of the people in the study who actually expressed feelings of discomfort belong to this group. Previous research has pointed at conceptions of punctuality (Birth, 2004), dealing with bureaucracy (Belabas \& Gerrits, 2017), and being uneasy when confronting cultural disparities (Khovanova-Rubicondo \& Pinelli, 2012) as being factors that can generate feelings of discomfort. The members of this group explicitly mention these aspects and that they find such behaviour unacceptable, that is, they lack coping tactics.

The members in the third cluster express a desire to belong to the wider Portuguese society and to actively contribute through work, time, energy or expertise to the hosting society because it makes them feel happy. They do it by learning the language, mingling with natives and so forth. Following the findings of Chow (2007) and Wu et al. (2012), such relation building with the natives creates a sense of belonging. By moving around for daily tasks like shopping or working, the space becomes familiar and a sense of feeling at home is built (Antonsich, 2010; Juang et al., 2018). In order to overcome structural constraints (Datta et al., 2007) and to adapt to the everyday practices of the new community, coping tactics emerge, which to some extent have been learned from interacting with natives (Machado et al., 2019). The members of this group feel a strong sense of belonging to the local Portuguese community in which they live and have developed different tactics to deal with practical problems in their daily life. Many of the respondents in this group report that they share the norms and values of the community in which they live, which facilitates the socialisation process (Kaasa et al., 2016). Consequently, they reduce their feelings of discomfort and increase their sense of belonging. Moreover, returning to Sweden is not an option they tend to consider.

Embedding is a process that occurs over time, in specific contexts and to varying degrees, as a result of on-going commitments and opportunities (Ryan \& Mulholland, 2015). This study shows that those practicing privilege are very happy indeed with practicing privilege in the 'expat bubble'. But others are keen on participating in different activities with the local population leading to embedding, that is, an increase in the sense of belonging and place attachment.

The length of residence in Portugal influences the self-perception of integration, and roughly speaking, the Swedes who have been living for a longer time in the country show stronger feelings of being part of the social milieux. As stated by Cuba and Hummon (1993), time gives people the opportunity to grow emotional ties to locales, changing space into place. However, this process is not linear and variables like the purpose of migrating to Portugal intersect with social and economic issues, elevating the complexity of understanding how self-perceived integration is built.

When discussing the findings of this paper, some methodological reflections are needed. Contrary to most studies on expats, this study focuses mainly on persons outside the 'expat bubble'. When searching for respondents through social media, we got in touch with another category of ordinary people from Sweden, working in ordinary professions and earning ordinary salaries. A common denominator for these persons is that they feel that they want to integrate into the new country. Also, the drivers behind their move to Portugal differ from those in the first group, and indeed, few of them are eligible for tax exemption

\section{8 | CONCLUDING REMARKS}

This study discusses the self-perceived integration of Swedish citizens holding a permanent residence permit in Portugal, as well as the tactics they devise to build a feeling of being part of a social whole. Four questions were proposed to be answered.

In answer to the first question of how the Swedes see their place of residence, the small group practicing privilege living in an expat 'bubble' has little sense of belonging to the place they live in and considers the idea of leaving when the privileges attached to their status end. To them, 'home' is in Sweden, whereas where they live is 'here'. But the majority of the Swedes in the study have a strong sense of belonging to the place where they live. They consider Portugal as 'home' and not Sweden. A similar pattern is displayed when answering the second question of how the Swedes interact with the Portuguese. Those practicing privilege have few (if any) contacts with the Portuguese, and their only interaction with the locals is when they need to deal with public bureaucracy or local craftsmen. 
However, the majority group of the study actively interacts with the Portuguese. The third question of how the Swedes live in Portugal displays that Swedes in Portugal are not simply one homogeneous group. Whereas those practicing privilege have bought their housing in gated communities, screened off from ordinary people, few of the 'ordinary' Swedes have done so. Because they cannot afford to buy their own housing, they often rent and live amidst the Portuguese community.

The fourth question dealt with how important Swedes permanently residing in Portugal consider proficiency in the Portuguese language for becoming a part of the local community. Somewhat unsurprisingly, the small group practicing privilege has no intention of becoming part of the local community. They hardly interact with the Portuguese and Portuguese society, and they have little ambition to do so. Hence, they display little interest in mastering the Portuguese language. However, the majority of the respondents consider proficiency in Portuguese as an important tool to become part of the local community and to function in Portuguese society. Thus, language proficiency is considered as a tool for becoming integrated.

An important methodological reflection is that any self-perceived perspectives on integration will indeed be subjective. Some of the interviewees have a strong sense of belonging and have developed tactics to handle any feelings of potential discomfort. From their perspective and with their preferences, this may be true, but this says nothing about to what extent the Portuguese and Portuguese society consider them to be integrated. Thus, to what extent Swedes (as well as other EU migrants) who are permanently residing in Portugal are considered as integrated by the Portuguese and the local communities in which they live could pose an interesting topic for future research.

Another avenue for future research could be to study how Portugal utilises the human capital and competence brought by Swedes and other EU migrants. Many of them are highly skilled and of working age. Especially, far from all of them have come to Portugal for retirement. So far, the focus in research has been on retirement and lifestyle migration from EU countries and on third country nationals. The outflow of highly skilled Portuguese to other EU countries has gained more interest than the inflow of highly skilled in working ages from other EU countries. Yet they exist, but they are typically underemployed.

The main added value of this paper is that we manage to show that the integration of Swedes in Portugal is a story with several tales. One tale tells the story of well-off people with little interest in Portugal and the Portuguese, and what matters to them are immediate benefits such as tax exemptions. The second tale tells a completely different story about ordinary people who are not wealthy or prominent. These people feel that they want to be integrated into their new country, they learn Portuguese, some work for Portuguese employers, they socialise with natives, and they live amidst the native population. A third tale is about those who are exploring the new country, learning the language, and trying to make a living in the new country. These three stories appear in parallel and simultaneously; however, it is a story seldom told.

\section{CONFLICT OF INTEREST}

None.

\section{ORCID}

Daniel Rauhut (D) https://orcid.org/0000-0002-9146-9984

Alina Esteves (D) https://orcid.org/0000-0001-8187-8664

\section{REFERENCES}

Aftonbladet. (2019). Slut på sötebrödsdagar i Portugal. 16.5.2019 [accessed on 12.5.2020].

Åkerlund, U. (2015). Strategic lifestyle management in later life: Swedish lifestyle movers in Malta seeking the 'best of both worlds'. Population, Space and Place, 23(1), 1-13. https://doi.org/10.1002/psp.1964

Åkerlund, U., \& Sandberg, L. (2015). Stories of lifestyle mobility: Representing self and place in the search for the 'good life'. Social \& Cultural Geography, 16(3), 351-370. https://doi.org/10.1080/ 14649365.2014.987806

Ampudia de Haro, F., \& Gaspar, S. (2019). Visados Dorados para Inversores en España y Portugal: Residencia a Cambio de Dinero. Arbor, 195/791: a495, 195, 495. https://doi.org/10.3989/arbor.2019.791n1008

Antonsich, M. (2010). Searching for belonging-An analytical framework. Geography Compass, 4(6), 644-659. https://doi.org/10.1111/j.17498198.2009.00317.x

Baumeister, R. F., \& Leary, R. (1995). The need to belong: Desire for interpersonal attachments as a fundamental human motivation. Psychological Bulletin, 117(3), 497-529. https://doi.org/10.1037/0033-2909. 117.3.497

Belabas, W., \& Gerrits, L. (2017). Going the extra mile? How street-level bureaucrats deal with the integration of immigrants. Social and Policy Administration, 51(1), 133-150. https://doi.org/10.1111/spol. 12184

Benson, M. (2009). A desire for difference: British lifestyle migration to southwest France. In M. Benson, \& K. O'Reilly (Eds.), Lifestyle migrations: Expectations, aspirations and experiences (pp. 121-136). Aldershot: Ashgate.

Benson, M. (2013). Living the 'real' dream in la France profonde? Lifestyle migration, social distinction, and the authenticities of everyday life. Anthropological Quarterly, 86(2), 501-525.

Benson, M., \& Osbaldiston, N. (2016). Toward a critical sociology of lifestyle migration: Reconceptualizing migration and the search for a better way of life. The Sociological Review, 64(3), 407-423.

Birth, K. K. (2004). Finding time: Studying the concepts of time used in daily life. Field Methods, 16(1), 70-84. https://doi.org/10.1177/ $1525822 \times 03259229$

Casado-Díaz, M. (2006). Retiring to Spain: An analysis of difference among North European nationals. Journal of Ethnic and Migration Studies, 32(8), 1321-1339.

Chow, H. (2007). Sense of belonging and life satisfaction among Hong Kong adolescent immigrants in Canada. Journal of Ethnic and Migration Studies, 33(3), 511-520. https://doi.org/10.1080/ 13691830701234830

Croucher, S. (2012). Privileged mobility in an age of globality. Societies, 2 (1), 1-13. https://doi.org/10.3390/soc2010001

Cuba, L., \& Hummon, D. M. (1993). Constructing a sense of home: Place affiliation and migration across the life cycle. Sociological Forum, 8(4), 547-572.

Dagens Arena. (2017). Finansministern läxar upp skatteflyende pensionärer. 20.1.2017 [accessed on 12.5.2020].

Datta, K., Mcllwaine, C., Evans, Y., Herbert, J., May, J., \& Wills, J. (2007). From coping strategies to tactics: London's low-pay economy and migrant labour. British Journal of Industrial Relations, 45(2), 404-432. https://doi.org/10.1111/j.1467-8543.2007.00620.x

Davis, K. (1949). Human society. New York: The MacMillan Company. 
De Certeau, M. (1984). The practice of everyday life. Berkeley: University of California Press.

Esser. (2001). Integration und Etnische Schichtung. Working paper no. 40. Mannheim: Mannheimer Zentrum für Europäische Sozialforschung.

Esteves, A., \& Sampaio, D. (2013). Language proficiency among immigrants and the establishment of interethnic relations: A comparative analysis of Bilbao, Lisbon and Rotterdam. Finisterra, XLVIII/96, 65-88. https:// doi.org/10.18055/Finis3617

Fechter, M. (2007). Living in a bubble: Expatriates' transnational spaces. In V. Amit (Ed.), Going first class: New approaches to privileged travel and movement (pp. 33-52). New York: Berghahn Books.

Gabinete de Estratégia e Planeamento. (2018). Estrangeiros no Mercado de Trabalho em Portugal-2017, Análises e Notas Técnicas. In Lisboa. Ministério do Trabalho, Solidariedade e Segurança Social.

Garcés-Mascareñas, B., \& Penninx, R. (2016). Introduction: Integration as a three-way process approach? In B. Garcés-Mascareñas, \& R. Penninx (Eds.), Integration processes and policies in Europe. Contexts, levels and actors (pp. 1-9). Heidelberg: Springer.

Haldrup, M. (2004). Laid-back mobilities: Second-home holidays in time and space. Tourism Geographies, 6(4), 434-454. https://doi.org/10. 1080/1461668042000280228

Hayes, M. (2015). Moving south: The economic motives and structural context of North America's emigrants in Cuenca, Ecuador. Mobilities, 10(2), 267-284. https://doi.org/10.1080/17450101.2013.858940

Heckmann, F. (2006). Integration and integration policies. IMISCOE Network Feasibility Study.

Hellgren, Z. (2016). Immigrant integration as a two-way process: Stakeholder discourses and practices in Stockholm and Barcelona. Psychosociological Issues in Human Resource Management, 4(1), 143-167.

Herbers, K. (2017). Os alemães em Aljezur: casos de lifestyle migration. Master's thesis in Culture and Society in Europe, Faculty of Arts and Humanities, University of Lisbon.

Instituto Nacional de Estatística. (2019). Estatísticas da Construção e Habitação: 2018. Lisboa: Instituto Nacional de Estatística.

Instituto Nacional de Estatística. (2020). Statistical database. [Accessed on 18.10.2020]. www.ine.pt

Juang, L. P., Simpson, J. A., Lee, R. M., Rothman, A. J., Titzmann, P. F., Schachner, M. K., ... Betsch, C. (2018). Using attachment and relational perspectives to understand adaptation and resilience among immigrant and refugee youth. American Psychologist, 73(6), 797-811. https://doi.org/10.1037/amp0000286

Kaasa, A., Vadi, M., \& Varblane, U. (2016). A new dataset of cultural distances for European countries and regions. Research in International Business and Finance, 37, 231-241. https://doi.org/10.1016/j.ribaf. 2015.11.014

Khovanova-Rubicondo, K., \& Pinelli, D. (2012). Evidence of the economic and social advantages of intercultural cities approach. Meta-analytic assessment. Strasbourg: Council of Europe.

King, R., Warnes, T., \& Williams, A. (2000). Sunset lives: British retirement migration to the Mediterranean. Oxford: Berg Publishers.

Könnilä, P. (2014). Sisua ja mañanaa. Suomalaiset Espanjan Aurinkorannikolla. Turku: Migration Institute.

Korpela, M. (2009). When a trip to adulthood becomes a lifestyle: Western lifestyle migrants in Varanasi, India. Lifestyle migration: Expectations, aspirations and experiences. In M. Benson, \& K. O'Reilly (Eds.), Lifestyle migration: Expectations, aspirations and experience (pp. 15-30). Aldershot: Ashgate.

Lestegás, I., Lois-Gonzáles, R. C., \& Seixas, J. (2018). The global rent gap of Lisbon's historic centre. International Journal of Sustainable Development and Planning, 13(4), 683-694. https://doi.org/10.2495/SDPV13-N4-683-694

Liu, S., Liu, Y., \& Wang, S. (2020). Constructing a sense of home: Older Chinese migrants ageing in a foreign land. Journal of Sociology. https://doi. org/10.1177/1440783320927083
Machado, B., McGarrigle, J., Fonseca, M. L., \& Esteves, A. (2019). Migrant welfare tactics and transnational social protection between Portugal and the UK. Finisterra, LIV/112, 27-43. https://doi.org/10.18055/ Finis17809

McAuliffe, M., Kitimbo, A., Goossens, A., \& Ahsan Ullah, A. (2018). Understanding migration journeys from migrants' perspectives. In M. McAuliffe, \& M. Ruhs (Eds.), World migration report 2018 (pp. 171-189). Geneva: International Organization for Migration.

Montezuma, J., \& McGarrigle, J. (2018). What motivates international homebuyers? Investor to lifestyle 'migrants' in a tourist city. Tourism Geographies, 21(2), 214-234. https://doi.org/10.1080/14616688. 2018.1470196

Morén-Alegret, R., \& Wladyka, D. (2019). International immigration, integration and sustainability in small towns and villages: Socioterritorial challenges in rural and semi-rural Europe. London: Palgrave Macmillan.

O'Reilly, K. (2000). The British on the Costa del Sol. London: Routledge.

O'Reilly, K. (2012). International migration and social theory. London: MacMillan.

O'Reilly, K. (2017). The British on the Costa del Sol twenty years on: A story of liquids and sediments. Nordic Journal of Migration Research, 7 (3), 139-147.

Oliveira, C. R., \& Gomes, N. (2019). Indicadores de Integração de Imigrantes 2019. Lisboa: Observatório das Migrações, ACM.

Olsson, E. (2017). The guide to comfort. The diasporic practices of Swedish clubs in Southern Spain. Nordic Journal of Migration Research, 7(3), 156-164.

Palese, E. (2013). Zygmunt Bauman. Individual and society in the liquid modernity. SpringerPlus, 2:191 (http://www.springerplus.com/ content/2/1/191).

Raminhos, M. M. (2004). Fronteiras da Identidade. O "Outro" na Construção de um Lugar na Serra de Grândola. Oeiras: Celta Editora.

Rauhut, D. (2020a). Integration and informal institutions. Society, 57(2), 211-218. https://doi.org/10.1007/s12115-020-00467-6

Rauhut, D. (2020b). Why Swedes move to Portugal: Drivers and motives. A paper presented at the 27th Conference of the Associação Portuguesa para o Desenvolvimento Regional, 10-11 September 2020 in Angra do Heroísmo, Terceira, Azores, Portugal.

Rauhut, D., \& Laine, J. P. (2020). Swedish immigration to Portugal: A bordering perspective. Journal of Borderland Studies, 1-16. https://doi. org/10.1080/08865655.2020.1777888

Reitz, J. G., \& Banerjee, R. (2009). Racial inequality and social integration. In J. R. Reitz, R. Breton, D. K. Kisiel, \& K. L. Dion (Eds.), Multiculturalism and social cohesion: Potentials and challenges of diversity (pp. 123-155). New York: Springer.

Robson, C. (2002). Real world research. Oxford: Blackwell.

Rubin, A., \& Babbie, E. (2010). Research methods for social work. Belmont: Wadsworth Publishing.

Ryan, L., \& Mulholland, J. (2015). Embedding in motion: Analysing relational, spatial and temporal dynamics among highly skilled migrants. In L. Ryan, U. Erel, \& A. D'Angelo (Eds.), Migrant capital: Networks, identities and strategies (pp. 135-153). London: Palgrave Macmillan.

Sampaio, D. (2011). Migrações pós-reforma em áreas de baixa densidade do Algarve: um olhar da geografia na perspectiva do desenvolvimento local. Master's thesis, Institute of Geography and Spatial Planning, Universidade de Lisboa.

Sardinha, J. (2015). Idyllic seekers and liminal beings: Lifestyle migrants in Central Portugal. In K. Torkington, I. David, \& J. Sardinha (Eds.), Practising the good life: Lifestyle migration in practices (pp. 33-51). Newcastle upon Tyne: Cambridge Scholar's Publishing.

Schellenberg, G. (2004). Perceptions of Canadians: A sense of belonging, confidence, and trust. Canadian Social Trends, 75, 16-21.

Scuzzarello, S. (2020). Practising privilege. How settling in Thailand enables older Western migrants to enact privilege over local people. Journal of 
Ethnic and Migration Studies, 46(8), 1606-1628. https://doi.org/10. 1080/1369183X.2020.1711570

Swiss Economic Forum. (2020). População Estrangeira Residente em Portugal, Database https://sefstat.sef.pt/forms/distritos.aspx [accessed on 18.10.2020].

Swedish Pensions Agency. (2019). Statistical database, www. pensionsmyndigheten.se [accessed on 5.12.2019].

Torkington, K. (2015). 'The only Portuguese people I know speak English': Lifestyle migrants, local language practices and ambivalent belongings. In K. Torkington, I. David, \& J. Sardinha (Eds.), Practising the good life: Lifestyle migration in practices (pp. 218-233). Newcastle upon Tyne: Cambridge Scholar's Publishing.

Torkington, K., \& Perdigão Ribeiro, F. (2019). A place in the sun? Discursive constructions of positive outcomes in post-migration stories in the Algarve. Social \& Cultural Geography, 20(5), 671-691. https://doi. org/10.1080/14649365.2017.1373145

Wu, Z., Schimmel, C., \& Hou, F. (2012). Self-perceived integration of immigrants and their children. Canadian Journal of Sociology, 37(4), 381-408.

How to cite this article: Rauhut D, Esteves A. Becoming a part of 'elsewhereness': On the self-perceived integration of Swedish immigrants in Portugal. Popul Space Place. 2020; e2423. https://doi.org/10.1002/psp.2423 